\title{
Molecular and morphological analysis of an Antarctic tardigrade, Acutuncus antarcticus
}

\author{
Hiroshi KAGOSHIMA, ${ }^{1,2}$ Satoshi IMURA, ${ }^{3}$ Atsushi C. SUZUKI ${ }^{4 *}$ \\ ${ }^{1}$ Transdisciplinary Research Integration Center, Research Organization of Information and Systems (ROIS), Toranomon 4-3-13, Minato-ku, \\ 105-0001 Tokyo; ${ }^{2}$ National Institute of Genetics, ROIS, Yata 1111, Mishima, 411-8540 Shizuoka; ${ }^{3}$ National Institute of Polar Research, \\ 10-3, Midoricho, Tachikawa, 190-8518 Tokyo; ${ }^{4}$ Department of Biology, Keio University, 4-1-1 Hiyoshi, 223-8521 Yokohama, Japan \\ *Corresponding author: chu@a6.keio.jp
}

\begin{abstract}
We isolated a species of tardigrade from moss samples collected from Langhovde and Skarvsnes, near Syowa station, East Antarctic, from which we cultured a parthenogenetic strain in Petri dishes with co-occurring cyanobacteria or green algae. This culture was maintained at both 4 and $10^{\circ} \mathrm{C}$, though the latter proved more suitable for growth. Eggs were laid free, rather than in exuviae. We isolated the 18S rRNA sequences from this tardigrade, identical to that of Acutuncus antarcticus from King George island, South Shetland islands. Morphological analyses via both light and scanning electron microscopy also show general agreement with characteristics of A. antarcticus: dorsal and ventral apophyses for the insertion of stylet muscles and dorsal longitudinal thickening on the anterior part of buccal tube; presence of pharyngeal apophyses, two macroplacoids and absence of a microplacoid; the surface structure of egg; and claw shape. Peribuccal lamellae were absent, but six oval swellings surrounded the mouth opening. An additional study of moss pillars from lake Hotoke-ike, Skarvsnes, proved the existence of the same tardigrade taxon living at the bottom of the lake.
\end{abstract}

Key words: Tardigrada, antarctica, cultivation, exuviae, JARE (Japanese Antarctic Research Expedition), $18 S$ rRNA.

\section{INTRODUCTION}

A number of tardigrades have been described near Syowa station, the Japanese Antarctic research station $\left(69^{\circ} 00^{\prime} \mathrm{S}\right.$ and $\left.39^{\circ} 35^{\prime} \mathrm{E}\right)$ on East Ongul island, LutzowHolm bay, East Antarctica. Morikawa (1962) studied about 100 tardigrade individuals from a pond on the island, including four Diphascon ongulense (Morikawa, 1962) and the remainder described as Hypsibius arcticus (Murray, 1907) which is now considered as Acutuncus antarcticus (Richters, 1904) (Dastych, 1991; Pilato and Binda, 1997). Sudzuki (1964) described six species from moss samples collected at Langhovde, about $20 \mathrm{~km}$ south of the Ongul islands, including: Hypsibius antarcticus (Richters, 1904) (now A. antarcticus; Dastych, 1991), Hypsibius mertoni shimoizumii Sudzuki, 1964 (now considered as synonym of $A$. antarcticus; Dastych, 1991), Diphascon langhovdense (Sudzuki, 1964) Dastych, 2002, two unidentified hypsibids and Milnesium tardigradum Doyère, 1840. Later, Utsugi and Ohyama (1989) reported that $H$. arcticus was widely distributed close to Syowa station and both $H$. arcticus and D. ongulense at Langhovde.

The identification problems associated with older records resulted from limited information are problematic for modern nomenclature. Moreover, $H$. arcticus was often confused with $H$. antarcticus but the existence of $H$. arcticus in the Antarctic region is now thought doubtful (Dastych, 1991). Furthermore, Pilato and Binda (1997) erected a new genus Acutuncus with the original Macro- biotus antarcticus Richters, 1904 as the type species. Therefore, all $H$. arcticus reported from the Syowa station environs are now recognised as $A$. antarcticus, one of the most widespread species in Antarctica (McInnes, 1995). We felt it timely to confirm this assumption by re-examining the taxa found around Syowa station with modern molecular methods as well as ultrastructure morphology. We analysed the genomic sequence, morphology and lifehistory of $A$. antarcticus, collected from moss near Syowa station, to discuss the circumstances and problems surrounding previous records of this species.

\section{METHODS}

Antarctic moss samples were collected at Skarvsnes (S69 $\left.{ }^{\circ} 29.751^{\prime} \mathrm{E} 39^{\circ} 37.818^{\prime}\right)$ and Langhovde (S69 $9^{\circ} 14.511^{\prime}$ E39 $9^{\circ} 43.713^{\prime}$ ), Soya coast, East Antarctica (Fig. 1), on 7 and 13 February 2011, respectively, during the $52^{\text {nd }}$ Japanese Antarctic Research Expedition (JARE-52, 2010-2012). The samples were enclosed in plastic bags and stored in a $4^{\circ} \mathrm{C}$ refrigerator after collection. Living tardigrades were isolated from the samples and transferred to a plate containing 1.8\% agar, 1x Bold Modified Basal Freshwater Nutrient Media (BMBFN) (Sigma Aldrich Inc., St Louis, MO, USA) and $5 \mu \mathrm{g} \mathrm{mL}^{-1}$ cholesterol with thin layer of distilled water (about $5 \mathrm{~mL}$ for $10 \mathrm{~cm}$ diameter plate). They were cultivated under dim light for a $12 \mathrm{~h}$ photoperiod at 4 or $10^{\circ} \mathrm{C}$ with about $200 \mu \mathrm{L}$ of water containing algae, bacteria, and fungi also extracted from the moss. To establish an iso- 
genic line of this parthenogenetic species, a single young female tardigrade without mature gonad was picked and transferred to a new plate for several generations. Each process was operated in sterile conditions to avoid contamination. The cultures were maintained by transferring 1020 tardigrades to a new BMBFN plates with water containing cyanobacteria and green algae, twice a year. Small amount of distilled water were supplied to keep thin layer on the surface of the agar every two months.

Three tardigrades of the isogenic line were individually transferred to $20 \mu \mathrm{L}$ of $0.25 \mathrm{~N} \mathrm{NaOH}$ in $0.2 \mathrm{~mL}$ tubes, and kept at room temperature for $12 \mathrm{~h}$ (Stanton et al., 1998). This lysate was then heated for $3 \mathrm{~min}$ at $95^{\circ} \mathrm{C}$, and $4 \mu \mathrm{L}$ of $1 \mathrm{M} \mathrm{HCl}$ and $10 \mu \mathrm{L}$ of $0.5 \mathrm{M}$ Tris- $\mathrm{HCl}(\mathrm{pH} 8.0)$ were added

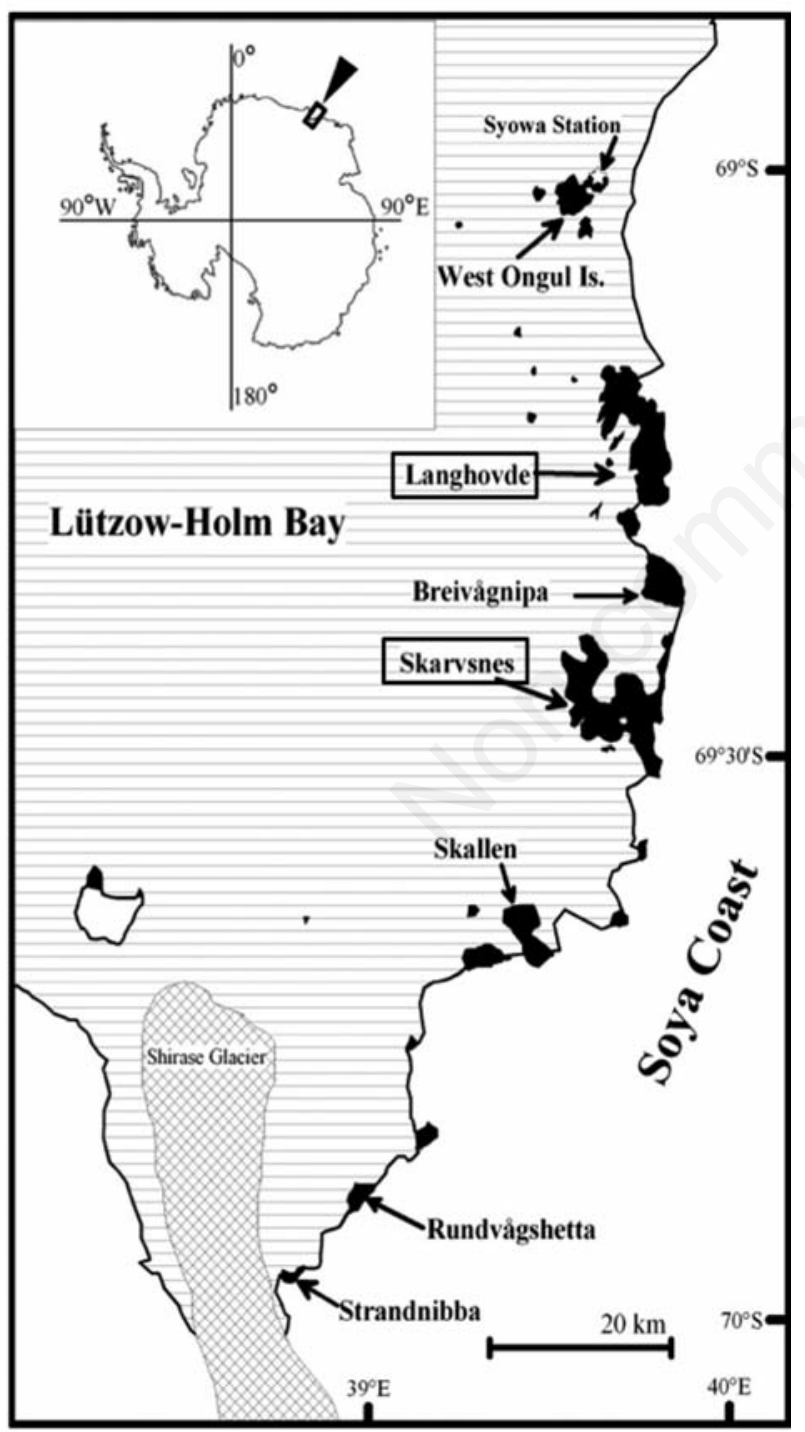

Fig. 1. The location of Syowa station (box in the upper left corner) and sampling sites. to neutralize the base followed by $1 \mu \mathrm{L}$ of $2 \%$ Triton X100. The lysate was heated for a further $3 \mathrm{~min}$ at $95^{\circ} \mathrm{C}$ and stored at $-20^{\circ} \mathrm{C}$ until further processing. Polymerase Chain Reaction (PCR) amplification was subsequently performed on genomic $18 \mathrm{~S}$ rDNA, 28S rDNA loci and mitochondrial cytochrome oxidase c subunit 1 (COI) locus in a $20 \mu \mathrm{L}$ reaction volume, containing $0.5 \mu \mathrm{L}$ of lysate templates, $2 \mu \mathrm{L}$ of $10 \mathrm{x}$ reaction buffer with $2.5 \mathrm{mM} \mathrm{MgCl} 2$, dNTP-mix at $200 \mu \mathrm{M}$ each, $1 \mu \mathrm{M}$ each primer and a 0.5 unit of ExTaq polymerase (Takara Bio Inc., Otsu, Japan). The PCR primer sequences used for 18S rDNA were SSU04F (GCTTGTCTCAAAGATTAAGCC) and SSU81R (TGATCC$(\mathrm{A} / \mathrm{T})(\mathrm{T} / \mathrm{G}) \mathrm{C}(\mathrm{C} / \mathrm{T}) \mathrm{GCAGGTTCAC})$ (Blaxter et al., 1998), those used for the D2D3 region of 28S rDNA were used \#391 (AGCGGAGGAAAAGAAACT) and D3B (TCGGAAGGAACCAGCTACTA) (De Ley et al., 1999), and for COI were LCO1490 (GGTCAACAAATCATAAGATATTGG) and HCO2198 (TAAACTTCAGGGTGACCAAAAAATCA) (Sands et al., 2008). PCR conditions were: $94^{\circ} \mathrm{C}$ for $2 \mathrm{~min}$, followed by 40 cycles of $94^{\circ} \mathrm{C}$ for $10 \mathrm{sec}, 52^{\circ} \mathrm{C}$ for $30 \mathrm{sec}$, and $72^{\circ} \mathrm{C}$ for $1 \mathrm{~min}$, for 40 cycles, and $72^{\circ} \mathrm{C}$ for $10 \mathrm{~min}$ (Kagoshima et al., 2012). PCR products were separated by agarose gel electrophoresis and purified using QIAquick Gel Extraction kit (Qiagen, Germantown, MD, USA). Sequencing reactions were performed with Big-Dye terminator cycle sequencing kits, and run on the ABI 3130xl analyser (Applied Biosystems, Foster City, CA, USA). Sequences were assembled and compared with published sequences in GenBank by BLAST search (Altschul et al., 1997).

Additional samples were extracted from specimens of an Antarctic moss pillar collected on January 19, 2000, during the JARE-42, at lake Hotoke-ike $\left(69^{\circ} 280\right.$ S, $39^{\circ} 340$ E), Skarvsnes, about $50 \mathrm{~km}$ south of Ongul island. These moss specimens were stored at $-40^{\circ} \mathrm{C}$, thawed once for the metagenomic analysis by Nakai et al. (2012), and the remainder was refrozen and stored at $-20^{\circ} \mathrm{C}$. We thawed this material and filtered through $1 \mathrm{~mm}$ and $32 \mu \mathrm{m}$ mesh screens, examining the $32 \mu \mathrm{m}$ fraction by stereomicroscope. Genomic analysis of the tardigrades extracted from the moss pillar samples was carried out as above.

Specimens for light microscopy were initially fixed for a few minutes in acetic acid before moving to $10 \%$ formalin, and mounted on slides with glycerol or Hoyer's medium. They were observed with Olympus BX-50 differential interference contrast (DIC) microscope equipped with a digital camera (NEX-5N; Olympus Corporation, Tokyo, Japan). Measurements were made using the Photoshop (Adobe) digital image measurement tool. The $p t$ ratio following Pilato (1981) was used for comparison, i.e. the ratio of the buccal tube length to the length of any sclerotised parts, which is expressed as a percentage in brackets (Tab. 1). For scanning electron microscopy (SEM), fixed specimens were dehydrated in a series of $t$ - 
butanol (2-methyl-2-propanol), freeze dried in a JEOL JFD-320, mounted on aluminium stabs and observed with JEOL JSM-6510 at $10-15 \mathrm{kV}$.

\section{RESULTS}

\section{Culture}

Tardigrades were extracted from moss colonies [Bryum pseudotriquetrum (Hedw.) G. Gaertn., B. Mey. \& Scherb., Bryum argenteum Hedw. and Ceratodon purpureus (Hedw. (Brid.)] collected from the two sites, Skarvsnes and Langhovde, Soya coast, East Antarctica. Although we cannot certify the original locality of the cultured tardigrades, each sample site produced the same tardigrade species. The tardigrades from the moss samples were first isolated and put on an agar plate on 8 June 2011 under a dim light at 10 and $4{ }^{\circ} \mathrm{C}$. After two months, we found a number of tardigrades feeding on cyanobacteria or green algae isolated from the moss samples. On 25 August 2011 six individual tardigrades were isolated with cyanobacteria and green algae and transferred to separate plates, which were maintained at 4 or $10^{\circ} \mathrm{C}$. After three months, tardigrades were observed in all six dishes, but more animals had reproduced at 10 than $4^{\circ} \mathrm{C}$. An isogenic line was chosen and it has, to date, been maintained for 17 months.

Tardigrades were observed walking slowly on the agar and apparently feeding on either cyanobacteria or green algae. In life, the body appeared transparent or white under dark field illumination as a result of the storage cells that fill all the post-head body (Fig. 2a). Large eyes were always present and the intestine was usually green but sometimes grey-green while faeces were often a much

Tab. 1. Measurements in $\mu \mathrm{m}$ and [ $p t$ ratio] of a Hoyer specimen and three glycerol specimens of adults.

\begin{tabular}{|c|c|c|c|c|}
\hline & Hoyer & Glycerol 1 & Glycerol 2 & Glycerol 3 \\
\hline Body length & 452.9 & 403.2 & 410.4 & 373.8 \\
\hline Buccal tube length & $42.5[100.0]$ & $40.6[100.0]$ & $42.0[100.0]$ & $35.3[100.0]$ \\
\hline Buccal tube width & $4.5[10.6]$ & $4.2[10.3]$ & $4.5[10.7]$ & $4.1[11.6]$ \\
\hline Stylet support insertion & $27.5[64.7]$ & $26.9[66.3]$ & $28.6[68.1]$ & $23.0[65.2]$ \\
\hline $1^{\text {st }}$ Macroplacoid & $6.3[14.8]$ & $6.8[16.7]$ & $6.9[16.4]$ & $5.7[16.1]$ \\
\hline $2^{\text {nd }}$ Macroplacoid & $5.5[12.9]$ & $5.8[14.3]$ & $6.0[14.3]$ & $5.1[14.4]$ \\
\hline Placoid row length & $14.3[52.0]$ & $14.6[54.3]$ & $14.9[52.1]$ & $12.7[55.2]$ \\
\hline Pharynx length & $37.7[88.7]$ & $43.1[106.2]$ & $42.0[100.0]$ & $35.6[100.8]$ \\
\hline Internal claw, $1^{\text {st }}$ leg & $17.7[41.6]$ & $16.2[39.9]$ & $18.0[42.9]$ & n.d. \\
\hline External claw, $1^{\text {st }}$ leg & $25.2[59.3]$ & $22.9[56.4]$ & $22.2[52.9]$ & $23.3[66.0]$ \\
\hline Anterior claw, $4^{\text {th }}$ leg & $16.9[39.8]$ & $18.0[44.3]$ & n.d. & $15.4[43.6]$ \\
\hline Posterior claw, $4^{\text {th }}$ leg & $27.3[64.2]$ & $31.2[76.8]$ & n.d. & $26.3[74.5]$ \\
\hline
\end{tabular}

n.d., not determined.
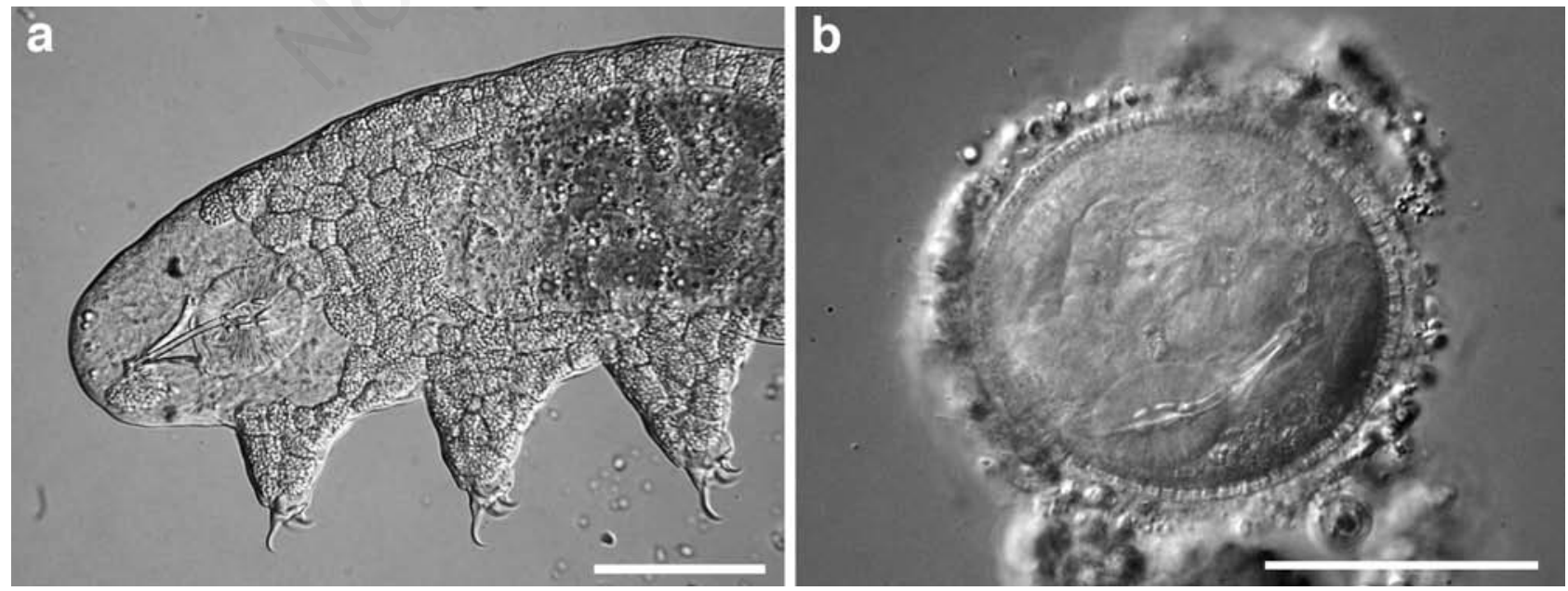

Fig. 2. The live images of cultured tardigrade (using a differential interference contrast microscope). a) Anterior profile; b) egg. The bucco-pharyngeal apparatus of the embryo is seen in it. Many algal cells are attached to the egg-shell surface. Scale bars of a) and $b)=50 \mu \mathrm{m}$. 
brighter green than the environmental algae. Eggs are mostly laid freely, i.e. not in the exuvia. The sticky surfaces are often covered with algae and other detritus particles. Bucco-pharyngeal apparatus of the embryo often visible in the egg (Fig. 2b). Most exuviae were found without eggs, though there were a few, rare occasions when eggs were seen in the old skins. Although the natural shape of the exuviae was not fully extended, rounded slightly, their length should represent their development profile. Therefore, we provide a histogram of the length of seventy-eight exuviae measured from their natural images under stereomicroscope (Fig. 3).

\section{Morphology}

Morphological characters of cultured tardigrades were observed on one adult specimen mounted in Hoyer's medium and three mounted in glycerol (Figs. 4 and 5; Tab. 1). Surface ultrastructures were observed with SEM specimens (Figs. 6a-d). Body length, 373.8-452.9 $\mu \mathrm{m}$; cuticle smooth;
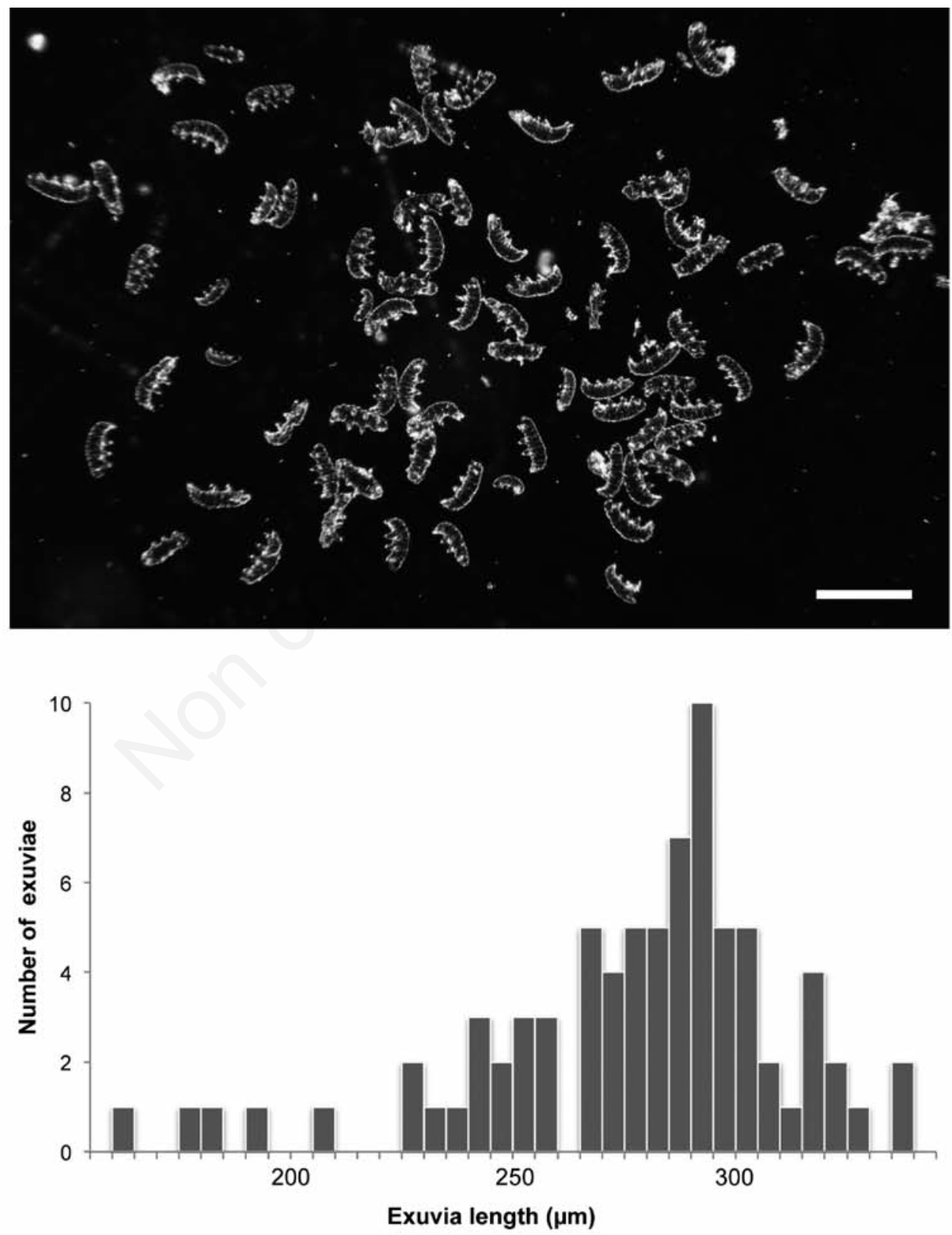

Fig. 3. Exuviae of cultured tardigrades. Stereomicroscope image (top) and the histogram of the length of seventy-eight exuviae (bottom). Scale bar $=500 \mu \mathrm{m}$. 
mouth situated antero-ventrally. Buccal apparatus Acutuncus-type; buccal tube 35.3-42.5 $\mu \mathrm{m}$ long and 4.1-4.5 $\mu \mathrm{m}[\mathrm{pt}$ 10.3-11.6] wide. The stylet support inserted at 23.0-28.6 $\mu \mathrm{m}$ [pt 64.7-68.1]. Dorsal and ventral apophyses for the stylet muscles of buccal tube, in lateral view, with dorsal longitudinal thickening behind the apophysis (Fig. 5a). The pharynx nearly spherical with apophyses and two macroplacoids (Fig. 5b), first macroplacoid 5.7-6.9 um [pt 14.8-16.7] long and slightly constricted in the middle (Fig. 5b); second macroplacoid 5.1-6.0 um [pt 12.9-14.4] long. First/second macroplacoid ratio 1.1-1.2. Microplacoid absent (Fig. 5b). Placoid row 12.7-14.9 um [pt 52.0-55.2]. Peribuccal lamina or papilla absent but the SEM image shows six oval structures surrounding the mouth opening (Fig. 6c).

Claws asymmetric, external claw longer than the internal on legs I-III (leg I, 16.2-18.0 $\mu \mathrm{m}$ and 22.2-25.2 $\mu \mathrm{m}$, respectively) and posterior claw longer than the anterior of leg IV (15.4-18.0 $\mu \mathrm{m}$ and 26.3-31.2 $\mu \mathrm{m}$, respectively) (Fig. 6b).

Eggshell consists of numerous spine or rod-like processes and outer transparent sheath (Fig. 6d). Dimensions of live eggs $(n=18)$ including eggshell in the long and short diameter are $80.9 \mu \mathrm{m}(\mathrm{SD}=6.0)$ and $75.2 \mu \mathrm{m}$ $(\mathrm{SD}=4.2)$, respectively. The mean thickness of the eggshell is $2.4 \mu \mathrm{m}(\mathrm{SD}=0.2)$. Egg processes have variable length and shape (Fig. 6d).

\section{Sequence analyses}

DNA amplification and sequencing of three individuals was successful for $18 \mathrm{~S}$ ribosomal RNA (rRNA) sequences, a highly variable region (D2-D3 region) of 28S rDNA sequences, and cytochrome oxidase subunit I (COI) gene in mitochondrial DNA (accession no. AB753790 for $18 \mathrm{~S}$ rRNA, AB753791 for 28S rRNA, and AB753792 for COI in DNA data bank of Japan (DDBJ)). The sequence read of $18 \mathrm{~S}$ rRNA was a perfect match to $A$. antarcticus previously reported from King George island (GenBank accession no. EU266943). No live tardigrades were recovered from a lake Hotoke-ike moss pillar sample, though eight individuals were extracted and analysed for 18S rRNA sequences. Seven samples were too decomposed and yielded only fungal sequences, but one sample provided the sequence (accession no. AB753858), which was identical to the tardigrade cultured from our terrestrial mosses.

\section{DISCUSSION}

A complicated situation had arisen around the identification of Acutuncus antarcticus until the re-discovery and the re-description of Richters (1904) type material by Dastych (1991) and the subsequent erection of new genus by Pilato and Binda (1997). The difficulty surrounding
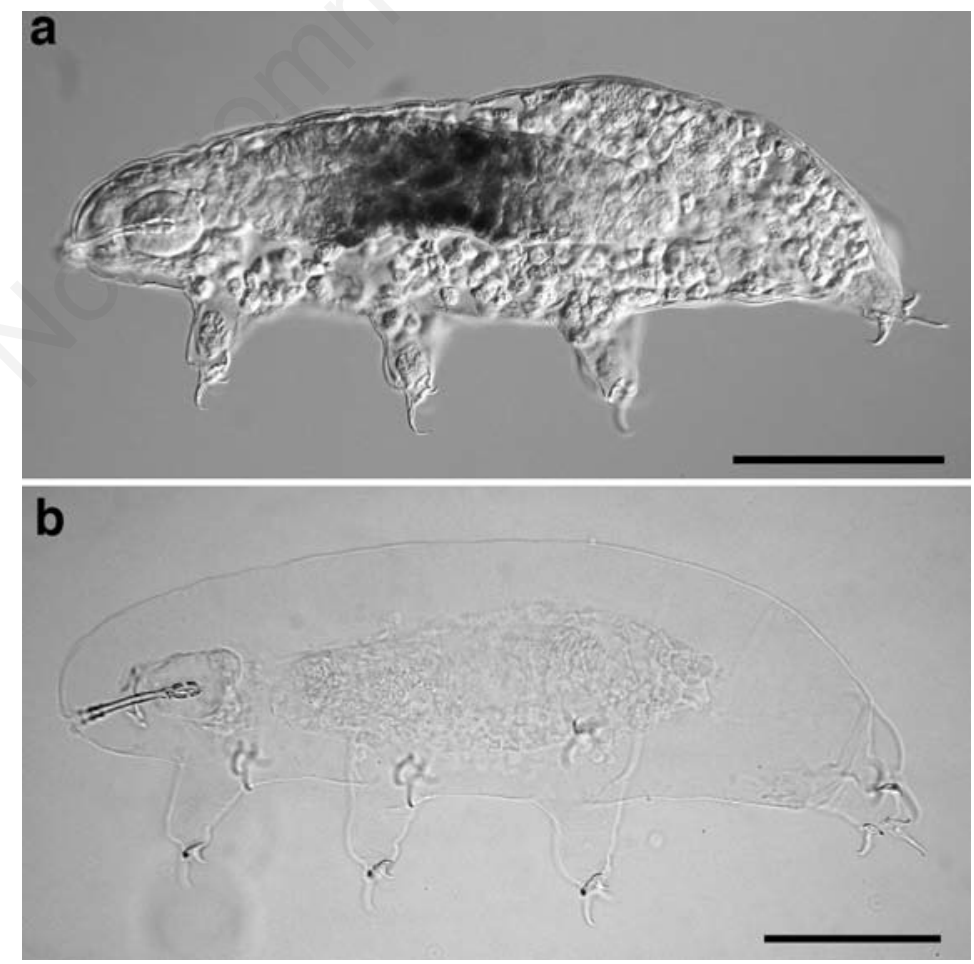

Fig. 4. Tardigrade specimens from the culture (using a differential interference contrast microscope). a) Mounted in glycerol; b) mounted in Hoyer's medium. Scale bars of a) and b) $=100 \mu \mathrm{m}$. 
the problematic Hypsibius arcticus has yet to be elucidated, which has neither type specimen nor sufficient original description.

The tardigrade cultured in the present study had identical DNA sequences to $A$. antarcticus from King George island, South Shetland islands, Maritime Antarctica (accession no. EU266943). Sands et al. (2008) mentioned the difficulty of identification prior to the molecular analysis; the voucher specimens of the registered sequence of $A$. antarcticus proved to be a mix of $A$. antarcticus with Hypsibius dujardini type and $H$. pallidus type. The latter two species, as is the norm for Hypsibius taxa, oviposit in exuviae. Therefore, even though these tardigrades are very difficult to distinguish, especially under a low magnification stereomicroscope, in live culture the usual mode of free oviposition of A. antarcticus may be a useful method to distinguish it from hypsibid tardigrades, which lay eggs in exuviae. Our cultured tardigrades usually produced free laid eggs, and the egg morphology, as well as other characteristics, showed good agreement with the re-described characters of $H$. antarcticus (Dastych, 1991). The detailed structures of the egg processes and the outer sheath were also confirmed by SEM in this study; however, the twelve peribuccal papulae described by Pilato and Binda (1997), and which was also adopted as a key character of the genus Acutuncus (Pilato and Binda, 2010), were not found in the present specimens, although six oval swellings were observed surrounding the mouth opening. The oval swellings could be the same structures described as peribuccal lobe (Schuster et al., 1980). Another key character, the dorsal and ventral apophyses for the stylet muscles agreed with the accentuated hooks diagram of Acutuncus type (Marley et al., 2011).

In the first record of tardigrades around Syowa station, Morikawa (1962) found $H$. arcticus in a small (about $2 \mathrm{~mL}$ ) clump of the blue-green algae and diatoms collected from a pond on Ongul island. Although the egg structure was sim-
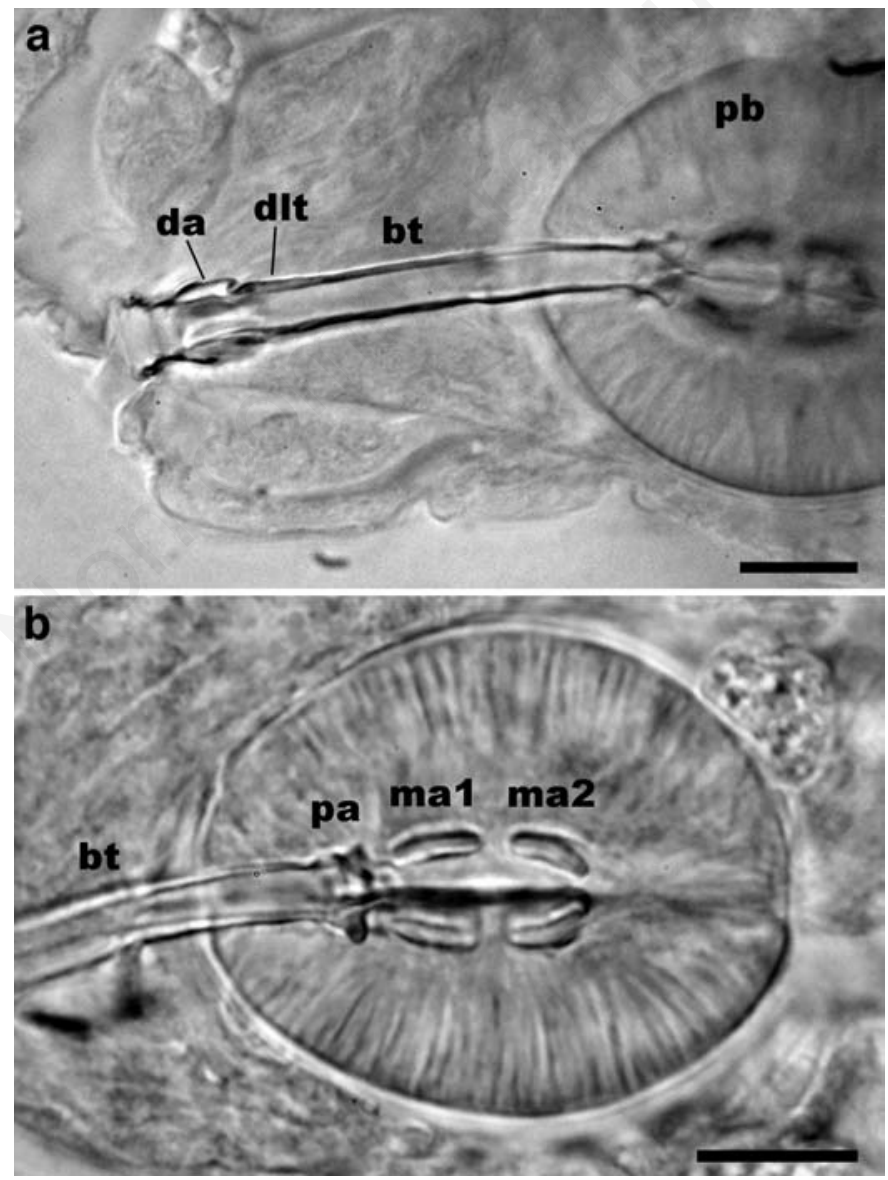

Fig. 5. The bucco-pharyngeal apparatus (using a differential interference contrast microscope). a) Lateral view of buccal tube; b) pharynx. $\mathrm{Bt}=$ buccal tube, $\mathrm{da}=$ dorsal apophysis for the insertion for stylet muscles, dlt=dorsal longitudinal thickening, $\mathrm{ma} 1=1^{\text {st }}$ macroplacoid, $\mathrm{ma} 2=2^{\text {nd }}$ macroplacoid, $\mathrm{pa}=$ pharyngeal apophysis, $\mathrm{pb}=$ pharyngeal bulb. Scale bars of a) and b) $=10 \mu \mathrm{m}$. 
ilar to that of $A$. antarcticus in respect to the egg shell with many protrusion and outer sheath, this tardigrade laid eggs in the exuvia. There is, therefore, the possibility that this $H$. arcticus was something other than $A$. antarcticus.

Sudzuki (1964) described a new subspecies H. mertoni shimoizumii, which was subsequently recognized as species H. shimoizumii by Ramazzotti and Maucci (1983), but now interpreted as a junior synonym of $H$. antarcticus (Dastych, 1991). There was no information about $H$. shimoizumii eggs (Sudzuki, 1964). Confusingly, Sudzuki (1964) also distinguish $H$. antarcticus with a smooth eggshell. None of these specimens have been preserved (Dastych, 1991) and, in this circumstance, we could derive no definitive information from this report.

Utsugi and Ohyama (1989) reported that H. arcticus was widespread in the area close to Syowa station. The egg morphology coincided well with $A$. antarcticus, but they described the eggs laid separately or in moulted $\mathrm{cu}$ - ticle (Utsugi and Ohyama, 1989). McInnes (1995) also described that the eggs of $H$. antarcticus ( $=A$. antarcticus) had been found both free and in exuvia. We suggest there might be two different species or a different strain, one with in exuvia mode of oviposition as described in $H$. arcticus. Alternatively, there might be two egg-laying strategies in the same parthenogenetic strain of $A$. antarcticus that are controlled by factors as yet not understood. In our cultured tardigrades, although oviposition in exuviae was actually observed, it occurred at a very low frequency. Therefore, another option is that the timing of egg-laying, i.e. before or after shedding exuvia, should be strictly kept in bisexual reproduction but may be loosely regulated in the parthenogenetic strain.

Dougherty (1964) reported on the cultivation of $H$. arcticus from freshwater algae at Ross island. His first trial with live tardigrades from a pond, was not successful, however, the culture succeeded with individuals from dried algal mat,
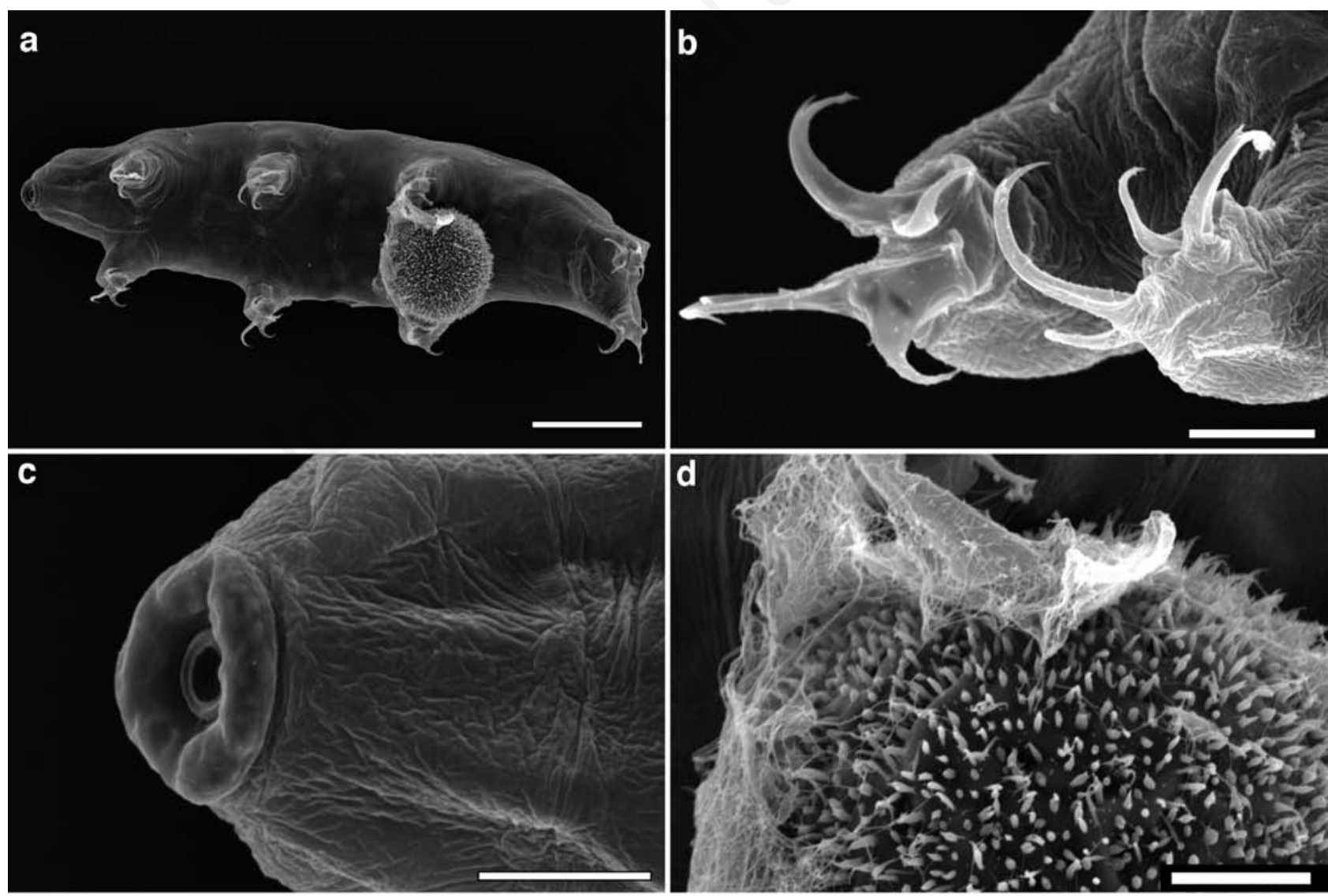

Fig. 6. Scanning electron microscopy-micrograph of the cultured tardigrade. a) Habitus. An egg is accidentally attached on the ventral side of this specimen at the third pair of the legs; b) claws of the 4th pair of leg; c) rostral part or the tardigrade. Six oval swellings surround the mouth opening; d) egg. Outer sheath, mostly broken in this photograph, comprises a mesh-like structure. Scale bars of $a)=50 \mu \mathrm{m}$, of $b-d)=10 \mu \mathrm{m}$. 
which demonstrated that this tardigrade was a freshwater species with the capacity for anhydrobiosis. Everit (1981) showed very high density (maximum 470 individuals/g wet weight algal mat) of $H$. arcticus $(=A$. antarcticus) in deep lake Tarn, Vestfold hills. In King George island, H. arcticus $(=A$. antarcticus $)$ dominated among most environments of ponds, streams and moss banks (Janiec, 1996). Nakai et al. (2012) found tardigrade gene sequences from the moss pillar at lake Hotoke-ike, Skarvsnes, which is a tower-like structure comprising mainly 243 algae and mosses (Imura et al., 1999). Their meta-genomic analysis revealed that the outer layer of the moss pillar was a good habitat for freshwater tardigrades (Nakai et al., 2012), showing the sub-dominant existence of two tardigrades showing high homology with 18S rRNA gene sequence of Diphascon pingue type and $A$. antarcticus. We confirmed the existence of tardigrades from the moss pillar, with one of these individuals exhibiting an identical 18S rRNA gene sequence with that of our cultured tardigrade. It is certain that $A$. antarcticus is widely distributed in Antarctica, including terrestrial moss, which is exposed to freezing and drying, and in the depths of the shallow lakes that do not freeze even in winter. An interesting question to ask is whether any genetic differences are found between the individuals living these two very different environments. Our cultured strain must therefore be a useful control or indicator for future research.

\section{CONCLUSIONS}

We succeeded in establishing a tardigrade culture from moss sampled near Syowa station, East Antarctica which feeds on cyanobacteria or green algae. 18S rRNA sequence confirmed its identity with Acutuncus antarcticus from South Shetland islands. Free laid eggs and morphological characters also agreed with the re-description of this species.

\section{ACKNOWLEDGMENTS}

We thank Dr. Satoshi Kobayashi and Takeshi Naganuma for providing Antarctic moss samples, and Dr. Ryosuke Nakai for preserving the moss pillar samples and his helpful discussion. Dr. Sandra McInnes and anonymous reviewers are also warmly thanked for reading and refining our manuscript. We greatly appreciate for the generous help of Professors Kohara and Niki of NIG. This research was supported by Grant-in-Aid for Scientific Research (No. 23247012 for S.I. and No. 23510239 for H.K.) from the Japan Society for the Promotion of Science.

\section{REFERENCES}

Altschul SF, Madden TL, Schaffer AA, Zhang J, Zhang Z Miller W, Lipman DJ, 1997. Gapped BLAST and PSI-BLAST: a new generation of protein database search programs. Nucleic Acids Res. 25:3389-3402.
Blaxter ML, De Ley P, Garey JR, Liuk LX, Scheldeman P, Vierstraete A, Vanfleteren JR, Mackey LY, Dorris M, Frisse LM, Vida JT, Thomas WK, 1998. A molecular evolutionary framework for the phylum Nematoda. Nature 392:71-75.

Dastych H, 1991. Redescription of Hypsibius antarcticus (Richters, 1904), with some notes on Hypsibius arcticus (Murray, 1907) (Tardigrada). Mitt. hamb. zool. Mus. Inst. 88:141-159.

Dastych H, 2002. Diphascon langhovdense (Sudzuki, 1964) stat. nov., a new taxonomic status for the semi-terrestrial tardigrade (Tardigrada). Acta Biol. Benrodis 12:19-25.

De Ley P, Félix M-A, Frisse LM, Nadler SA, Sternberg PW, Thomas WK, 1999. Molecular and morphological characterisation of two reproductively isolated species with mirror-image anatomy (Nematoda: Cephalobidae) Nematology 1:591-612.

Dougherty CE, 1964. Cultivation and nutrition of micrometazoa. II. An Antarctic strain of tardigrade Hypsibius arcticus (Murray, 1907) Marcus, 1928. T. Am. Microsc. Soc. 83:7-11.

Everitt EA, 1981. An ecological study of an Antarctic freshwater pool with particular reference to Tardigrada and Rotifera. Hydrobiologia 83:225-237.

Imura S, Bando T, Saito S, Seto K, Kanda H, 1999. Benthic moss pillars in Antarctic lakes. Polar Biol. 22:137-140.

Janiec K, 1996. The comparison of freshwater invertebrates of Spitsbergen (Arctic) and King George Island (Antarctic). Pol. Polar Res. 17:173-202.

Kagoshima H, Kito K, Aizu T, Shin-i T, Kanda H, Kobayashi S, Toyoda A, Fujiyama A, Kohara Y, Convey P, Niki H, 2012. Multi-decadal survival of an Antarctic nematode, Plectus murrayi, in a $-20^{\circ} \mathrm{C}$ stored moss sample. CryoLetters 33:280-288.

McInnes SJ, 1995. Tardigrades from Signy Island, South Orkney Islands, with particular reference to freshwater species. J. Nat. Hist. 29:1419-1445.

Marley NJ, McInnes SJ, Sands CJ, 2011. Phylum Tardigrada: a re-evaluation of the Parachela. Zootaxa 2819:51-64.

Morikawa K, 1962. Notes on some Tardigrada from the Antarctic region. Biol. Res. Jap. Ant. Res. Exp. 17:3-6.

Nakai R, Abe T, Baba T, Imura S, Kagoshima H, Kand H, Kohara Y, Koi A, Niki H, Yanagihara K, Naganuma T, 2012. Eukaryotic phylotypes in aquatic moss pillars inhabiting a freshwater lake in East Antarctica, based on 18S rRNA gene analysis. Polar. Biol. 35:1495-1504.

Pilato G, 1981. [Analisi di nuovi caratteri nello studio degli eutardigradi]. [Article in Italian]. Animalia 8:51-57.

Pilato G, Binda MG, 1997. Acutuncus, a new genus of Hypsibiidae (Eutardigrada). Entomol. Mitt. Zool. Mus. Hamb. 12:159-162.

Pilato G, Binda MG, 2010. Definition of families, subfamilies, genera and subgenera of the Eutardigrada, and keys to their identification. Zootaxa 2404:1-54.

Ramazzotti G, Maucci W, 1983. [Il Phylum Tardigrada]. [Article in Italian]. Terza Edizione riveduta e aggiornata. Mem. Ist. Ital. Idrobiol. 41:1-1012.

Richters F, 1904. [Vorläufiger Bericht über die antarktische Moosfauna]. [Article in German]. Verh. Deut. Z. 14:236239. 
Sands CJ, McInnes SJ, Marley NJ, Goodall-Copestake WP, Convey P, Linse K, 2008. Phylum Tardigrada: an 'individual' approach. Cladistics 24:861-871.

Schuster RO, Nelson DR, Grigarick AA, Christernberry D, 1980. Systematic criteria of the Eutardigrada. T. Am. Micros. Soc. 99:284-303.

Stanton JM, McNicol CD, Steele V, 1998. Non-manual lysis of second stage Meloidogyne juveniles for identification of pure and mixed samples based on polymerase chain reaction, Australas. Plant Pathol. 27:112-115.

Sudzuki M, 1964. On the microfauna of the Antarctic region. 1. Moss-water community at Langhovde. JARE Sci. Rep. 19:1-41.

Utsugi K, Ohyama Y, 1989. Antarctic Tardigrada. Proc. NIPR Symp. Polar Biol. 2:190-197. 